\title{
Potential of Botanicals and Biocontrol Agents against Rhizoctonia solani Kühn Incitant of Web Blight Disease of Mung Bean: An invitro Evaluation
}

\author{
Sadhna Chauhan*, L. B. Yadav, K. P. S. Kushwaha and Manoj Kumar Chitara \\ Department of Plant Pathology, College of Agriculture, \\ GBPU A\&T, Pantnagar Uttrakhand, 263145, India \\ *Corresponding author
}

\section{A B S T R A C T}

\begin{tabular}{|c|}
\hline Keywords \\
\hline $\begin{array}{l}\text { Botanicals, } \\
\text { bioagents, web } \\
\text { blight, Rhizoctonia } \\
\text { solani, Trichoderma } \\
\text { harzianum and } \\
\text { Pseudomonas } \\
\text { fluorescens }\end{array}$ \\
\hline Article Info \\
\hline $\begin{array}{l}\text { Accepted: } \\
20 \text { May } 2020 \\
\text { Available Online: } \\
10 \text { June } 2020\end{array}$ \\
\hline
\end{tabular}

The antagonistic activity of biocontrol agents and botanicals was evaluated against Rhizoctonia solani Kühn which is reputed as one of the destructive plant pathogens and a ubiquitous soil fungus. The pathogen causes huge losses in the production of mungbean in India. For this study, disease infected leaf samples were collected from pulse pathology block situated at Normon E. Borlaug Crop Research Centre, Pantnagar based on cultural, morphological and disease potential studies and then evaluated the pathogen against five botanicals viz. Calotropis, Ocimum, Aloevera, Neem and Bael at $5,15,25$ and 35 per cent concentration through poison food technique and two bioagents viz. Trichoderma harzianum (Th-14) and Pseudomonas fluorescens (Psf 173) by dual culture technique in the laboratory of the Department of Plant Pathology, College of Agriculture, GBPUA\&T, Pantnagar in 2017. Observations were taken after the full growth of the control in case of botanicals and after 24, 48 and 72 hours in case of biocontrol agents for the assessment of the inhibitory effects. In the presence of botanicals the variability in the growth inhibition over control was observed, as the maximum growth inhibition was observed in Calotropis @ 5, 15, 25 and $35 \%$ concentration (71, 81,84 and $86 \%$ ) and least in Aloevera (4.81, 10.56, 29.07 and 37.59 \%) respectively, likewise in the presence of bioagents maximum growth inhibition was observed in Trichoderma harzianum (Th-14) (61.29\%) and least in Pseudomonas fluorescens (Psf 173) (39.53\%) respectively. It was observed that all the botanical extracts and biocontrol agents resulted in significant reduction in the mycelial growth of Rhizoctonia solani in vitro.

\section{Introduction}

Mungbean or green gram, botanically Vigna radiata (L.) Wilczek belongs to the Leguminosae family, is one of the major pulse crops of the country. It is referred to as green gram, moong, mung, golden gram and is mainly grown for its highly proteinaceous and easily digestible seeds that are used for human consumption. Mungbean has wide application in agriculture, pharmaceuticals, food and cosmetics industries. Seeds and sprouts serve as functional foods that help in lowering the risk of several diseases and have health-promoting effects along with their nutritive value (Lambrides, 2007).

Mungbean has been shown to exert antidiabetic, antitumor, anti-inflammatory and antihypertensive effects through several different mechanisms (Matousek, 2009; Yao, 2008 and Lee, 2011). 
India is the leading producer of mungbean in the world. In India, during 2017-18, mungbean has a total area of about 40.70 lakh ha with the total production of 19.01 lakh tonnes and productivity $467 \mathrm{Kg} / \mathrm{ha}$ thus contributing to $13.86 \%$ area and $7.76 \%$ to total pulse production in the country (DES, Ministry of Agri. \& FW (DAC\&FW), Govt. of India; 2017-18). The major important diseases of mungbean include web blight (Rhizoctonia solani), cercospora leaf spot (Cercospora cruenta), anthracnose (Colletotrichum capsici), powdery mildew (Erysiphe polygoni), Macrophomina blight (Macrophomina phaseolina), bacterial leaf blight (Xanthomonas phaseoli Dc.), leaf crinkle (Urdbean leaf crinkle virus) and yellow mosaic (Mungbean Yellow mosaic virus) etc.

In world's warm and humid tropic regions, web blight of mungbean is among the chief serious constraints in its production. Also, it is considered as the most devastating fungal disease affecting mungbean leading to heavy yield losses especially in Uttar Pradesh and Uttarakhand's Tarai region (Sharma and Gupta, 2003). Infected plant debris harbours over summering/ overwintering pathogen (Onesirosan, 1975) while secondary spread relies on to dissemination of sclerotia and basidiospores (Saksena and Dwivedi, 1973; Onesirosan, 1975) as well as direct mycelium grown through plant parts during rainy weather and is favoured by relatively high temperature and moisture (Weber, 1939).

The plant products have been traditionally used to manage diseases much before fungicides were discovered. Antifungal compounds present in higher plants have long been known as an important factor for controlling diseases in plants (Avis, 2007; Mahadevan, 1982). Such compounds being biodegradable, eco- friendly and selective in their toxicity help in control some plant diseases (Zaker, 2016). Some of them are Azadirachta indica, Annona squamosa, Nicotiana tabacum, Derris roots, Chrysanthemum cinerariaefolium, Sabadilla officinale, Quasi amara, Ryania speciosa etc (Zakir, 2016; Buckinghum, 1993), likewise, biocontrol agents significantly reduced mycelial growth and sclerotia production, some of them are $T$. viride, T. harzianum and $G$. virens as fungal antagonists of Thanatephorus cucumeris, causal agent of aerial blight (Dubey, 2000; Dubey and Patel, 2001), efficacy of Trichoderma harzianum, Trichoderma viride and Pseudomonas fluorescens under in vitro conditions against $R$. solani have been found effective in inhibiting the mycelial growth of this fungus.

\section{Materials and Methods}

\section{Isolation of pathogen}

Collection of the mungbean leaves which showed the characteristic symptoms of the disease was made from the Pulse Pathology Block, Normon E. Borlaug Crop Research Centre, Pantnagar during August. The lesions, showing the initial and distinct characteristic symptoms, were selected for isolation of the pathogen. Leaves were washed with fresh and sterile water in order to remove the extraneous soil and surface contaminants were done.

Subsequently, young diseased tissues were cut into 2-3 $\mathrm{mm}$ pieces (containing 1/3 diseased and $2 / 3$ healthy portions) with a sterilized blade. With $1 \%$ sodium hypochlorite solution, these leaf bits were surface sterilized for 1-2 minutes and then afterwards washed thrice with sterile distilled water, so as to make them free from any traces of sodium hypochlorite. Then, these were placed on pre-sterilized blotter paper to make them devoid of any excess moisture under aseptic conditions in the inoculation 
chamber. The surface-sterilized diseased leaf pieces were subsequently aseptically transferred on sterilized Potato Dextrose Agar (PDA) slants and poured PDA medium on Petri plates (Chitara, 2017).

Similarly, sclerotia of test pathogen were also used for isolation. Before isolation, the surface of sclerotia was sterilized by dipping in $1 \%$ sodium hypochlorite solution for 1-2 minutes and thereafter thoroughly washed thrice in sterile distilled water, to remove any traces of sodium hypochlorite solution. Then, these sclerotia were transferred aseptically on sterilized Potato Dextrose Agar (PDA) slants and poured PDA medium on Petri plates (Chauhan, 2017).

Inoculated tubes and Petri plates were incubated in Biological Oxygen Demand (B.O.D.) incubator at $30 \pm 1^{\circ} \mathrm{C}$. After $48 \mathrm{hrs}$ of incubation, mycelial growth developed at margin was transferred to culture tubes containing PDA for further studies.

\section{Purification and maintenance of the culture}

The pathogen was purified by hyphal tip/single spore isolation method (Zhang et al., 2013). The culture obtained by this method was maintained on PDA slants and Petri plates. The subculturing of auxenic culture was done at an interval of fifteen days on fresh PDA slants and also stored in the refrigerator at $10^{\circ} \mathrm{C}$ for further studies.

\section{Identification of the isolate of $R$. solani}

The fungus culture was identified based on cultural and morphological characteristics. Slides were prepared and stained in lactophenol and examined under a compound microscope for morphological characteristics of the fungus. Five plants species were selected (Table 1) to estimate the antifungal property against $R$. solani of web blight of mungbean through poison food technique (McKinney, 1923). The plant species and parts used with their concentration are mentioned in Table 1.

Preparation of leaf and pulp extracts was done by cold water extraction technique described by Shekhawat and Prasad (1971) and Ansari (1995). Fresh leaves from different plants were thoroughly washed with tap water than in three changes of distilled water and surface sterilization was done with 2 per cent sodium hypochlorite solution and finally washed in distilled water. They were crushed in mortar pestle by adding distilled water @ 1 ml/g fresh weight $(1: 1 \mathrm{w} / \mathrm{v})$.

The extracts clarification was done by four layers of muslin cloth and then passing through Whatmann No. 1 filter paper. The filtered extracts were quoted in the study as 100 per cent extract. To prepare 5, 15, 25 and 35 per cent plant extract amended PDA medium (PEPDA), $5 \mathrm{ml}, 15 \mathrm{ml}, 25 \mathrm{ml}$ and 35 $\mathrm{ml}$ of plant extract was taken in flask separately and 95, 85, 75 and $65 \mathrm{ml}$ of double strength PDA medium was added in each flask respectively and shake well. These PEPDA were used in further studies.

Botanicals as 5, 15, 25 and $35 \%$ concentrations added to double strength sterilized PDA. Potato dextrose medium poisoned with various concentrations of different fungicides and botanicals was poured@20 ml per Petri plate aseptically. For each concentration of botanicals, three replications were maintained. After solidification of the medium, each plate was inoculated centrally with $5 \mathrm{~mm}$ disc cut/taken from the edge of 3 days old pure culture of $R$. solani using a sterilized sharp cork borer. Petri plates without botanicals inoculated with $R$. solani were served as check. All inoculated Petri plates were incubated at $30 \pm 1^{\circ} \mathrm{C}$. 
Radial growth was measured after inoculation with the help of measuring scale. Percent radial growth (mycelial) inhibition over control was calculated using the formula given below (McKinney, 1923).

$I=\frac{\mathrm{C}-\mathrm{T}}{\mathrm{T}} \times 100$

Where,

$\mathrm{I}=$ Per cent Inhibition

$\mathrm{C}=$ Colony diameter in control

$\mathrm{T}=$ Colony diameter in treatment

Two biocontrol agents namely, Trichoderma harzianum and Pseudomonas fluorescens were screened against $R$. solani under in vitro conditions by dual culture technique (Morton and Stroube, 1955). Trichoderma harzianum and Pseudomonas fluorescens formulations were obtained from Biocontrol Laboratory, Department of Plant Pathology, College of Agriculture, GBPUA\&T, Pantnagar.

For fungal bio-agent $20 \mathrm{ml}$ of sterilized melted PDA was poured in $90 \mathrm{~mm}$ Petri plate. After solidification of the medium, $5 \mathrm{~mm}$ disc of the antagonist and test fungus was cut with a sterilized cork borer from the edge of 3 days old culture and placed in line opposite to one other in a straight line at a distance of $5 \mathrm{~mm}$ from the edge.

For each treatment three replications were maintained and Petri plates without antagonist served as check/control. The inoculated Petri plates were incubated at temperature $30 \pm 1^{\circ} \mathrm{C}$ and linear growth of the bioagent was observed consecutively for several days to record various stages of the antagonism. Mycelial growth inhibition of $R$. solani by antagonist was recorded based on radial growth in dual culture and comparing that with control (having only $R$. solani) plate and the result was drawn by using formula given by McKinney, 1923.

\section{Statistical analysis}

The data were statistically analyzed with Completely Randomized Block Design (CRD) at the computer centre of G. B. Pant University of Agriculture and Technology, Pantnagar. The treatments were compared by the mean of critical differences (CD) at $5 \%$ level of significance.

\section{Results and Discussion}

In the present investigation, all the botanicals and bioagents were found effective in the suppression of radial growth of Rhizoctonia solani.

Effect of botanicals at the different concentration on Rhizoctonia solani under in-vitro condition

Antifungal activity of five botanicals extracts viz. Calotropis, Ocimum, Aloevera, Neem and Bael were assayed on the mycelial growth of $R$. solani is presented in Table 1 . The data shows significant inhibition in radial growth of $R$. solani in the respect of all the plant extract (Fig 1). It is varied with different botanicals and their concentration. A gradual increase in per cent inhibition of radial growth was seen as the concentration of the botanicals was increased. All of them were significantly different from one another at different concentrations. At 35 per cent concentration, maximum inhibition of radial growth $R$. solani was observed (Fig 2.). Among all the botanicals, Calotropis was found highly effective in reducing the radial growth of $R$. solani i.e. 86.00 per cent followed by Ocimum i.e. 75.00 per cent whereas minimum inhibition was recorded in Aloevera i.e. 37.59 per cent followed by bael i.e. 56.11 per cent and neem i.e. 42.22 per cent. Ansari (1995) determined the fungistatic activity of botanical extracts of Ocimum sanctum, Eucalyptus sp. and Mentha arvensis against $R$. solani. 
Table.1 Efficacy of different concentrations of botanicals on radial growth and inhibition per cent of $R$. solani at $30 \pm 1^{\circ} \mathrm{C}$

\begin{tabular}{|c|c|c|c|c|c|c|c|c|c|c|}
\hline \multirow[t]{2}{*}{ S.No. } & \multirow[t]{2}{*}{ Botanicals } & \multicolumn{9}{|c|}{ Concentrations $(\%) /$ Radial growth $(\mathrm{mm}) *$} \\
\hline & & $\begin{array}{c}\text { Plants parts } \\
\text { used }\end{array}$ & $5 \%$ & $\begin{array}{c}\text { Inhibition } \\
\text { over } \\
\text { check }(\%)\end{array}$ & $15 \%$ & $\begin{array}{c}\text { Inhibition } \\
\text { over } \\
\operatorname{check}(\%)\end{array}$ & $25 \%$ & $\begin{array}{c}\text { Inhibition } \\
\text { over } \\
\operatorname{check}(\%)\end{array}$ & $35 \%$ & $\begin{array}{c}\text { Inhibition } \\
\text { over check } \\
(\%)\end{array}$ \\
\hline 1. & Calotropis & Leaves & 26.33 & 71.00 & 17.50 & 81.00 & 14.17 & 84.00 & 12.83 & 86.00 \\
\hline 2. & Ocimum & Leaves & 63.67 & 29.00 & 37.83 & 58.00 & 26.67 & 70.00 & 22.50 & 75.00 \\
\hline 3. & Aloevera & Pulp & 85.67 & 4.81 & 80.50 & 10.56 & 63.83 & 29.07 & 56.17 & 37.59 \\
\hline 4. & Neem & Leaves & 74.33 & 17.41 & 70.83 & 21.30 & 61.00 & 32.22 & 52.00 & 42.22 \\
\hline 5. & Bael & Leaves & 78.50 & 12.78 & 75.17 & 16.48 & 69.00 & 23.33 & 39.50 & 56.11 \\
\hline \multirow[t]{5}{*}{6.} & Control & - & 90.00 & & 90.00 & & 90.00 & & 90.00 & \\
\hline & & & \multicolumn{2}{|c|}{ Botanicals (a) } & \multicolumn{3}{|c|}{ Concentration(b) } & \multicolumn{3}{|c|}{ Botanicals $\mathrm{x}$ Concentration (axb) } \\
\hline & S.Em. \pm & & \multicolumn{2}{|c|}{0.35} & \multicolumn{3}{|c|}{0.29} & \multicolumn{3}{|c|}{0.70} \\
\hline & $\mathrm{CD}(\mathrm{P}=\mathbf{0 . 0 5})$ & & \multicolumn{2}{|c|}{1.00} & \multicolumn{3}{|c|}{0.82} & \multicolumn{3}{|c|}{2.00} \\
\hline & $\mathbf{C V}$ & & & & \multicolumn{3}{|c|}{2.10} & & & \\
\hline
\end{tabular}

*mean of three replications

Table.2 In vitro efficacy of bioagents on radial growth and inhibition per cent of $R$. solani at $30 \pm 1^{\circ} \mathrm{C}$

\begin{tabular}{|c|c|c|c|c|c|}
\hline \multirow[t]{2}{*}{ S. No. } & \multirow[t]{2}{*}{ Bioagents } & \multicolumn{3}{|c|}{ Radial growth of $R$. solani* $(\mathrm{mm})$} & \multirow{2}{*}{$\begin{array}{c}\text { Inhibition over check } \\
(\%)\end{array}$} \\
\hline & & $24 \mathrm{Hr}$ & $48 \mathrm{Hr}$ & $72 \mathrm{Hr}$ & \\
\hline $\mathbf{1}$ & Th 14 & 14.17 & 24.17 & 34.83 & 61.29 \\
\hline 2 & Psf 173 & 18.83 & 38.50 & 54.42 & 39.53 \\
\hline \multirow[t]{2}{*}{3} & Check & 90.00 & 90.00 & 90.00 & \\
\hline & \multicolumn{2}{|c|}{ Bioagents (a) } & \multicolumn{2}{|c|}{ Hour(b) } & Interaction (axb) \\
\hline S.Em. \pm & \multicolumn{2}{|c|}{0.21} & \multicolumn{2}{|c|}{0.21} & 0.37 \\
\hline $\mathrm{CD}(\mathrm{P}=0.05)$ & \multicolumn{2}{|c|}{0.63} & \multicolumn{2}{|c|}{0.63} & 1.09 \\
\hline $\mathbf{C V}$ & & & \multicolumn{2}{|c|}{1.26} & \\
\hline
\end{tabular}




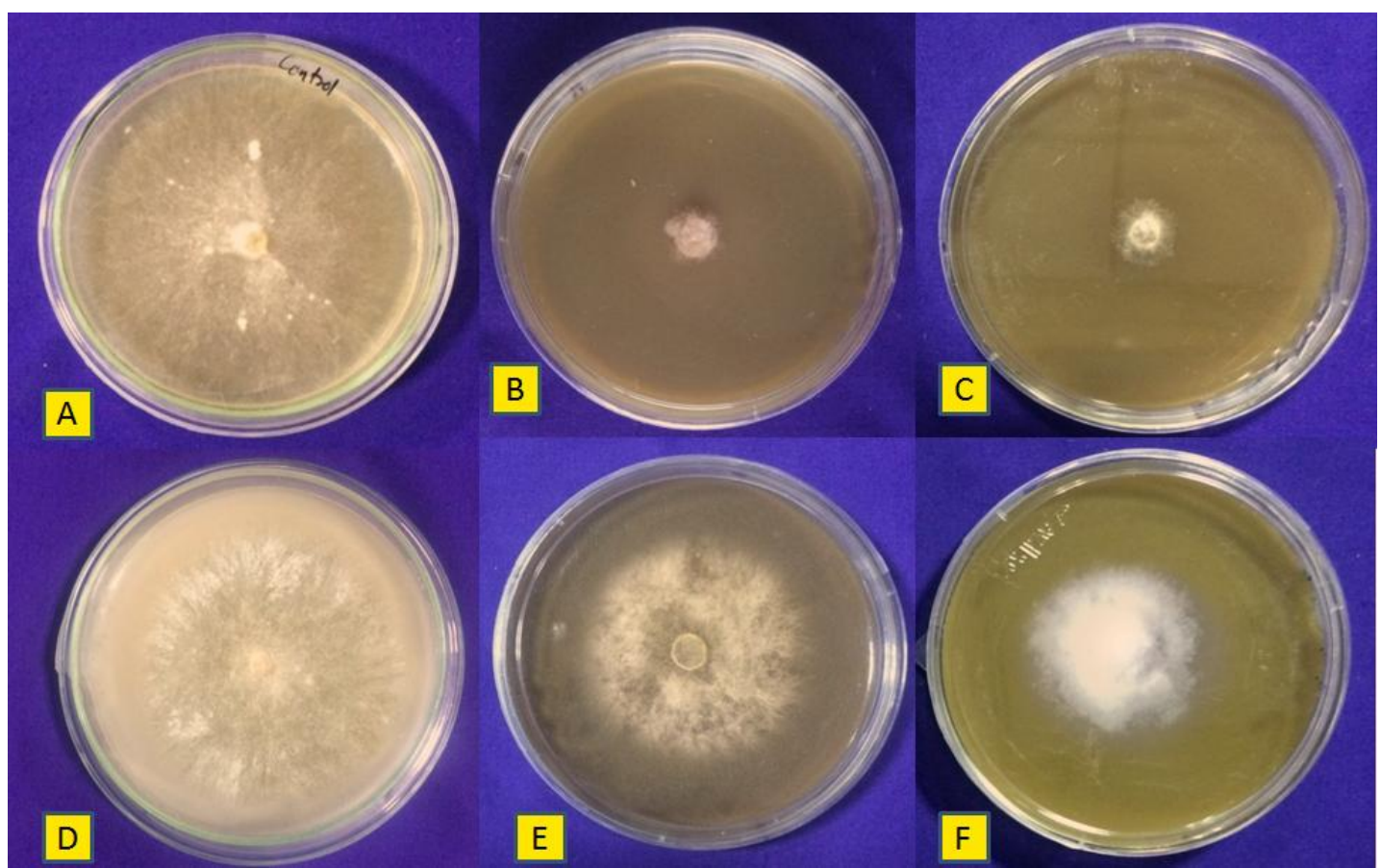

Fig.1 Effect of botanicals @ 35\% on mycelial growth of R. solani, Control (A), Calotropis (B), Ocimum (C), Aloevera (D), Neem (E) and Bael (F)

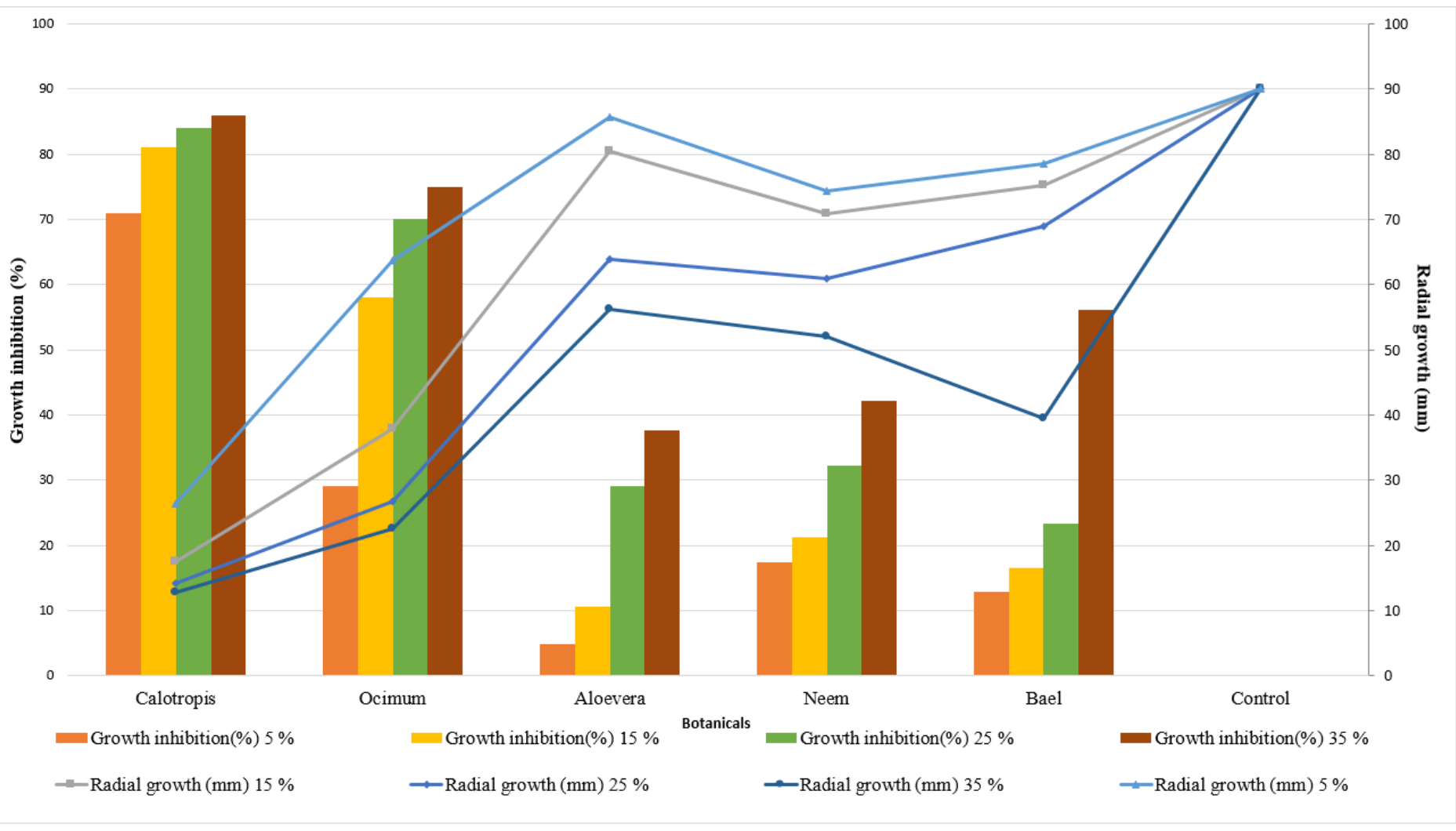

Fig.2 Efficacy of different concentrations of botanicals on radial growth and inhibition per cent of $R$. solani at $30 \pm 1^{\circ} \mathrm{C}$ 


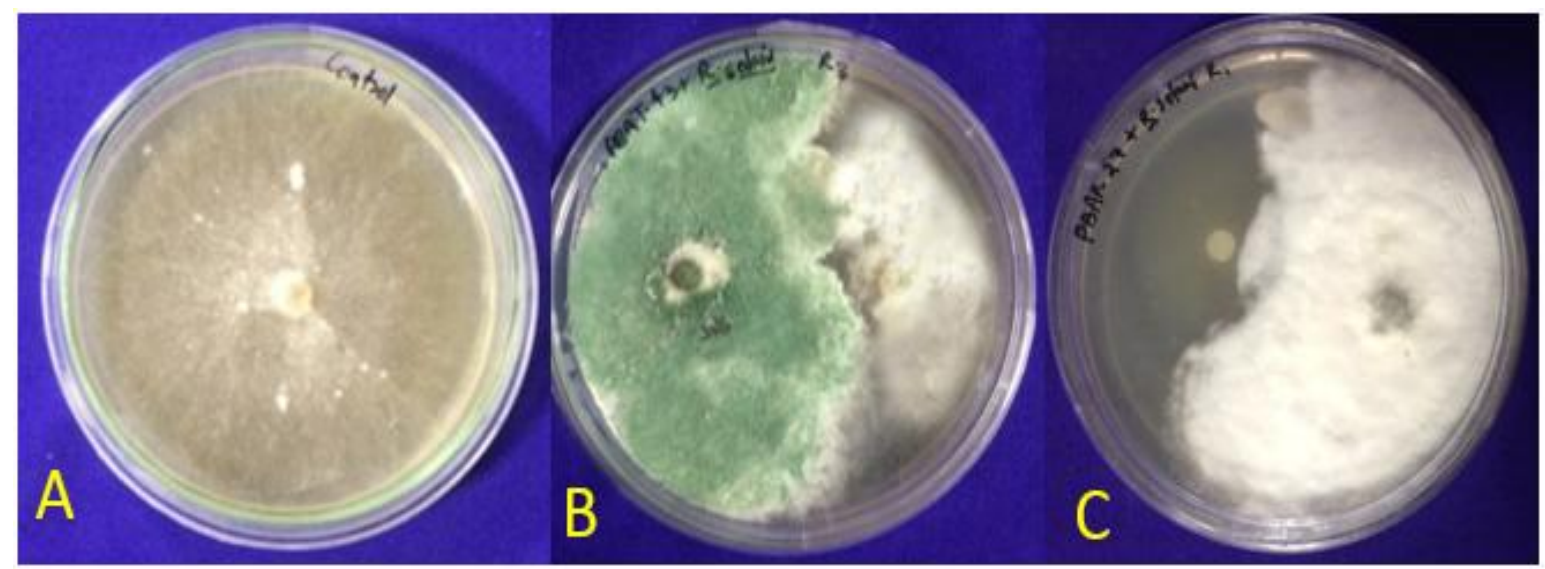

Fig.3 Effect of bioagents on mycelial growth of $R$. solani at $72 \mathrm{Hr}$,

Check (A), Th 14 and Psf 173 (C)

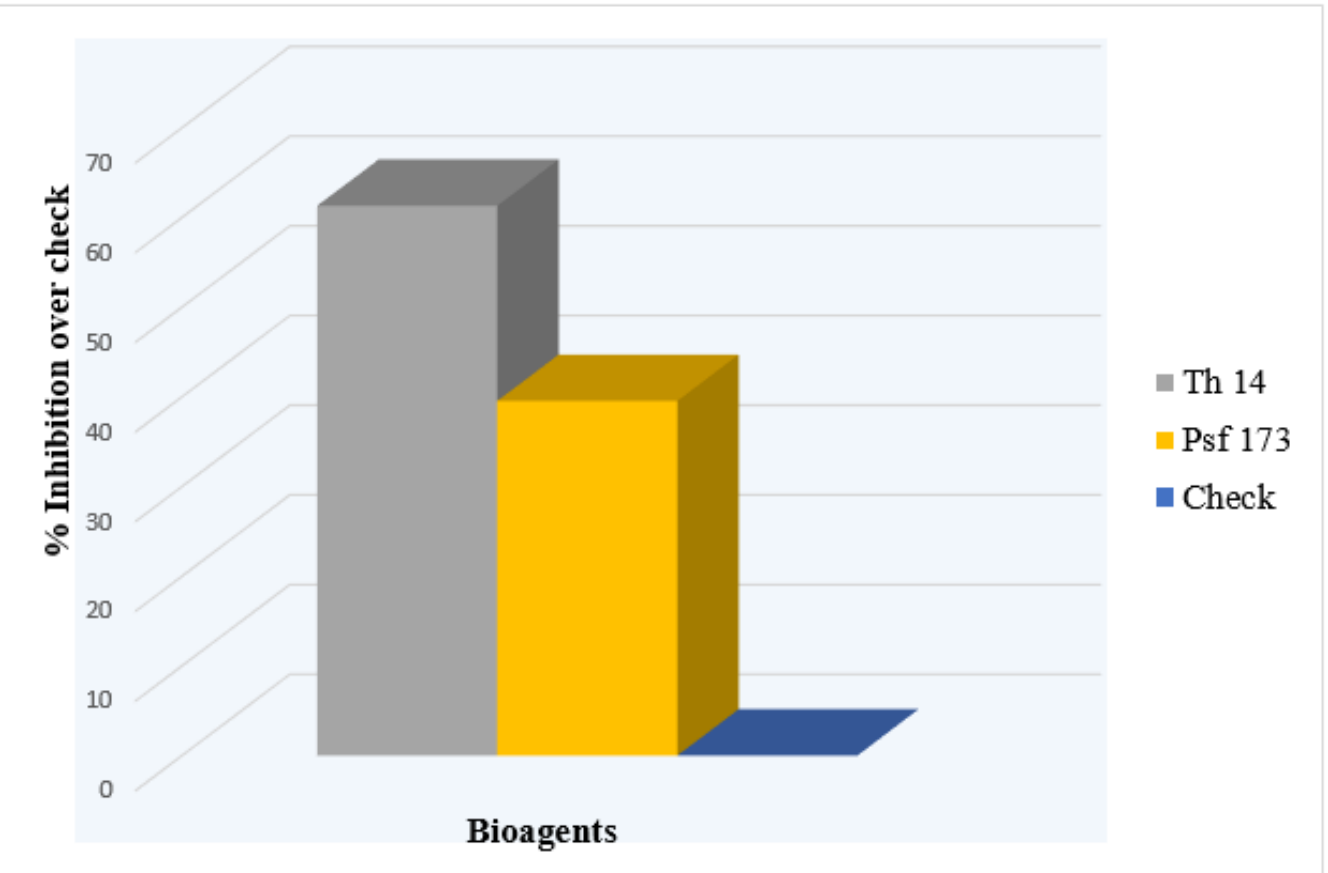

Fig.4 In vitro efficacy of bioagents on growth inhibition per cent of $R$. solani at $30 \pm 1^{\circ} \mathrm{C}$

Sonakar et al., (2014) found Calotropis most effective against $R$. solani causing aerial web blight of soybean under in vitro as at 5 per cent concentration, it showed 87.98 per cent inhibition in fungal radial growth.

\section{Effect of bioagents on Rhizoctonia solani under in-vitro conditions}

Under in vitro conditions, two biocontrol agents were evaluated against $R$. solani for their antagonistic activity by dual culture assay. The dual culture studies revealed as evident from Table 2 (Fig 4) that antagonist inhibited the growth of the pathogen significantly and inhibition zones were visible (Fig. 3). Based on observations recorded, it can be said that after 72 hours, Th-14 strain had the best inhibiting ability and the growth inhibition of $R$. solani was 61.29 per cent followed by bacterial isolate Psf 173 that showed inhibition per cent i.e. 39.53 as 
compared to check. The results so obtained indicated that Trichoderma harzianum was superior over Pseudomonas fluorescens by showing better growth inhibition of fungus, although $P$. fluorescens also had potential to inhibit the growth of pathogen but it was not as much effective as $T$. harzianum.

These findings are confirmatory with the findings of Dubey and Patel (2001) that reported Trichoderma harzianum resulted in cent per cent inhibition of mycelial growth of pathogen followed by Gliocladium virensand $T$. viride through production of volatile substances against Thanatephorus cucumeris causing web blight of mungbean. Meena et al., (2003) found Trichoderma harzianum effective in suppressing growth and sclerotia formation of $R$. solani through volatile activity.

It caused 80 per cent growth inhibition after $72 \mathrm{hr}$ of incubation and 33.5 per cent inhibition of sclerotia formation after 10 days of inoculation followed by $T$. viride, which caused 70 per cent growth inhibition and 25 per cent inhibition of sclerotia formation. Effect of the bacterial isolate was not found promising. Sharma et al., (2009) concluded that isolates of Trichoderma $s p$. were effective in suppressing the growth of $R$. solani.

Growth of an isolate of Trichoderma was directly associated with its ability to inhibit the pathogen. Initially, pathogen grew very fast as compared to the antagonist and covered almost the entire plate within $48 \mathrm{hr}$ but after $48 \mathrm{hr}$, the isolate of Trichoderma sp. started covering the pathogen and checked its further growth. But, there is still need for in vitro evaluation of other botanicals and isolates of Trichoderma sp. and Pseudomonas $s p$. against the pathogen which can assist in eco-friendly management of web blight disease of mungbean.

\section{Acknowledgement}

The authors are grateful to my Advisor Dr. L.B. Yadav, Dr. Karuna Vishunawat, Head of deparment and Dr. Roopali Sharma, Incharge, Biocontrol Laboratory, Department of Plant Pathology, College of Agriculture, GBPU A\&T, Pantnagar (Uttrakhand) for providing laboratory facilities and assistance to conduct the research.

\section{References}

Ansari, M.M. 1995. Control of sheath blight of rice by plant extracts. Indian Phytopath., 48: 268-270.

Avis, T.J. 2007. Antifungal compounds that target fungal membranes: applications in plant disease control. Canadian Journal of Plant Pathology, 29(4): 323329.

Buckingham, J. 1993. Dictionary of natural products, Chapman and Hall, London.

Chauhan, S. 2017. Etiology and management of web blight disease of mungbean incited by Rhizoctonia solani Kuhn (Doctoral dissertation, GB Pant University of Agriculture and Technology, Pantnagar-263145 (Uttarakhand).

Chitara, M. K. 2017. Studies on the Role of Colletotrichumine A on Anthracnose of Chilli (Capsicum annum L.) (Doctoral dissertation, Department of Mycology and Plant pathology, Institute of agricultural sciences, Banaras Hindu University, Varanasi.).

DES, Ministry of Agri. \& FW. Pulses Revolution from Food to Nutritional Security. $2018 . \quad$ farmer. gov.in/SucessReport 2018-19.pdf.

Dubey, S.C. 2000. Biological management of web blight of groundnut (Rhizoctonia solani). J. Mycol. Pl. Pathol., 30: 89-90.

Dubey, S.C. and Patel, B. 2001. Evaluation of antagonists against Thanatephorus 
cucumeris causing web blight of urd and mung bean. Indian Phytopath.,54: 206-209.

Lambrides C.J. and Godwin I. 2007. "Mungbean" in Genome Mapping and Molecular Breeding in Plants Pulses, Sugar and Tuber Crops Vol. 3 ed. Kole C., editor. (Berlin: Springer)., pp. 6990.

Lee S.J., Lee, J.H., Lee, H.H., Lee, S., Kim, S.H., Chun, T. and Imm, J.Y. 2011. Effect of mungbean ethanol extract on pro-inflammtory cytokines in LPS stimulated macrophages. Food Sci Biotechnol, 20(2): 519-524.

Mahadevan, A. 1982. Biochemical aspects of plant disease resistance part I. Preferred inhibitory substance prohibition. Today and Tomorrow Printer and Publishers, New Delhi.

Matousek, J., Podzimek, T., Pouckova, P., Stehlik, J., Skvor, J., Soucek, J. and Matousek, J. 2009. Antitumor effects and cytotoxicity of recombinant plant nucleases. Oncol Res. 18(4): 163-171.

Mckinney, H.H. 1923. Influence of soil temperature and moisture on infection of wheat seedling by Halminthosporium sativum. J. Agric. Res., 26: 195 - 210.

Meena, R.L., Rathore, R.S. and Mathur, K. 2003. Efficacy of biocontrol agents against Rhizoctonia solani f. sp. sasakii causing banded leaf and sheath blight of maize. J. Mycol. Pl. Pathol., 33(2): 310312.

Morton, D.J. and Stroube, W.H. 1955. Antagonistic and stimulatory effect of soil. Pp. 417-420.

Onesirosan, P.T. 1975. Seed borne and weed borne inoculum in web blight of cowpea. Pl. Dis. Reptr. 59: 338-339.

Ray, A., Kumar, P. and Tripathi, H.S. 2007. Evaluation of bioagents against Rhizoctonia solani Kuhn the cause of aerial blight of soybean. Indian
Phytopath. 60(4): 532-534.

Saksena, H.K. and Dwivedi, R.P. 1973. Web blight of blackgram caused by Thanatephorus cucumeris. Indian $\mathrm{J}$. Farm Sci. 1: 58-61.

Sharma, M. and Gupta, S.K. 2003. Ecofriendly methods for the management of root rot and web blight (Rhizoctonia solani) of French bean. J. Mycol. Pathol., 33(3): 345-361.

Sharma, N., Basant, P. and Avantina, S. 2009. Potential of endophytic fungi as bioagent against Rhizoctonia solani and Sclerotium rolfsii. J. Mycol. Pl. Pathol., 39(2): 266-270.

Shekhawat, P.S. and Prasad, R. 1971. Antifungal properties of some plant extracts; inhibition of spore germination. Indian Phytopathology. 24: 800-802.

Sonakar, V. K., Dasu, G. J., Maurya, K.K., Kushwaha, S.R., Maurya, A.K. and Ramesh, S. 2014. Efficacy of bio-agents and botanical extracts in control of Rhizoctonia solani causing aerial or web blight of soybean. Plant Archives, 14(2): 669-674.

Weber, G.F. 1939. Web blight, a disease of beans caused by Corticium microsclerotia. Phytopathology. 29: 559-575.

Yao, Y., Chen, F., Wang, M., Wang, J. and Ren, G. 2008. Antidiabetic activity of mung bean extracts in diabetic KK-Ay mice. J Agric Food Chem. 56(19): 8869-8873.

Zaker, M. 2016. "Natural plant products as eco-friendly fungicides for plant diseases control-A Review. The Agriculturists, 14(1): 134-141.

Zhang, K., Yuan-Ying, S. and Cai, L. 2013. An optimized protocol of single spore isolation for fungi. Cryptogamie, Mycologie, 34(4): 349-356. 


\section{How to cite this article:}

Sadhna Chauhan, L. B. Yadav, K. P. S. Kushwaha and Manoj Kumar Chitara. 2020. Potential of Botanicals and Biocontrol Agents against Rhizoctonia solani Kühn Incitant of Web Blight Disease of Mung Bean: An invitro Evaluation. Int.J.Curr.Microbiol.App.Sci. 9(06): 2627-2636. doi: https://doi.org/10.20546/ijcmas.2020.906.319 